were much lower than in 1939, the decline would not appear to be permanent; it is partly explained by heavy sales to the Continent.

The Union can supply processed fruit-jam, marmalade, canned fruit, dried fruit, fruit pulp and fruit juices-in substantial quantities. With some, e.g. dried fruit and fruit juices, the price obtainable militates against their sale in this market.

Other commodities. The Union can further supply a variety of other commodities in greater or smaller quantity. Substantial quantities of wines and brandy can be shipped and a number of minor products, such as tomato puree, chutney, jelly, at times pulses, and a newcomer, agar, are available, to mention only a few at random.

To summarize, although the Union cannot hope to equal the record of certain other countries in the supply of large quantities of basic foodstuffs to the United Kingdom, it nevertheless can make a substantial contribution, partly in basic, partly in semiluxury, foodstuffs to give variety to the British diet.

\title{
Recent Trends in the Sugar Industry of the British West Indies
}

\author{
By L. F. Wiggins, British West Indies Sugar Research Scheme, \\ Imperial College of Tropical Agriculture, Trinidad
}

The British Caribbean area is here regarded as consisting of Jamaica, Trinidad and Tobago, Barbados, the Leeward and Windward Islands, British Guiana and British Honduras. Although this area contributes to the British diet in many ways, for example by its exports of bananas, cocoa, citrus fruits, coconuts and, more recently, of tinned fruit juices and tomatoes, its chief contribution is sugar; no small quantity of rum obtained by the fermentation of molasses is also sent from the West Indies.

The value to this country of the sugar production of the West Indies and other Commonwealth countries and colonies has recently been brought home to us by the diminution in our sugar ration owing to our inability to buy very much sugar from dollar countries such as Cuba. Of the total sugar intake of this country in $194^{8}$, namely, 2,086,576 tons, hard currency areas contributed $1,083_{3,121}$ tons. It will therefore be to our advantage at this time of economic difficulty to increase our empire production of sugar so far as agreements with United States territories permit.

The value of sugar in nutrition has recently been emphasized by work carried out in America under the aegis of the Sugar Research Foundation (1949). For instance, Mack (1948) found, after large-scale experiments, that children given extra calories in the form of sugar attained a better skeletal development and general physique than others not so treated. Sugar grown either as beet or cane is certainly the most efficient food crop, giving rise to more calories/acre than any other.

\section{Possible measures to increase productivity of the West Indies}

The British West Indies has been described, doubtless truly, as the depressed area of the British Empire, and the people certainly deserve whatever help can be given to improve their prosperity. Since they depend, in some cases entirely, on sugar for their 
livelihood, any increase in sugar production is certain to be of great assistance, particularly because of the large numbers of workers that are needed for the cultivation of sugar-cane. Another way of increasing the prosperity of the West Indies would be in creating new industries based on sugar, and one function of the Colonial Products Research Council is to sponsor research that might lead to this end. One such subsidiary industry has in fact been launched recently. This is the manufacture of a yeast suitable for human consumption, and some aspects of the working of a food-yeast factory set up in Jamaica have been recently described (Floro, Williams, Flook \& Collier, 1948). Quite extensive researches are proceeding in both the United States and Great Britain designed to find and try new derivatives of sugar of use industrially. One such product, allyl sucrose, has been investigated by Nichols \& Yanovsky (1947) in the Eastern Regional Laboratory of the United States Government. This substance possesses properties which make it of interest as a varnish-type coating for wood. Certain degradation products of sugar are easily obtained and also offer the promise of being useful to chemical industry and to medicine. For example, alkaline reagents, such as lime, when heated with a sugar solution convert it into lactic acid in high yield, and this process may compete with the usual fermentation procedure of manufacture of this substance, inasmuch as the procedure is more rapid and more rigorously controlled. Alternatively, acid reagents degrade sugar and in this way 5 -hydroxymethylfurfural or levulinic and formic acids may be obtained (Haworth \& Wiggins, 1946, 1947). Numerous uses for these compounds and their derivatives have been indicated (Wiggins, 1949a) and researches are still being continued. The oxidation of sugar leads to several substances, among them potassium acid-saccharate. This is interesting because it is very similar to cream of tartar and it has recently been shown that it can be safely included in food products (Carr, 1947). Sufficient has perhaps been said on the utilization of sugar, especially since several reviews on this subject have been published recently (see Wiggins, $1949 b$ ).

\section{Recent expansion of the sugar industry of the British Caribbean area}

Let us now examine what improvements have been effected in the sugar industry of the Caribbean area particularly as they affect sugar production.

Table I (reproduced by courtesy of the West India Committee) shows the production

Table I. Cane-sugar production (in tons) in the British West Indies and British Guiana

\begin{tabular}{|c|c|c|c|c|c|}
\hline Country & $1945^{-6}$ & $1946-7$ & $1947-8$ & $1948-9$ & $\begin{array}{l}\text { Preliminary } \\
\text { estimate for } \\
1949-50\end{array}$ \\
\hline $\begin{array}{l}\text { Trinidad } \\
\text { Barbados }\end{array}$ & $\begin{array}{r}109,602 \\
\times 13,880\end{array}$ & $\begin{array}{r}10,069 \\
88,024\end{array}$ & $\begin{array}{r}115,941 \\
57,758\end{array}$ & $\begin{array}{l}159,032 \\
132,731\end{array}$ & $\begin{array}{l}156,200 \\
137,500\end{array}$ \\
\hline $\begin{array}{l}\text { Barbados } \\
\text { Jamaica }\end{array}$ & $\begin{array}{l}11,000 \\
\times 77,886\end{array}$ & $\begin{array}{r}00,024 \\
170,255\end{array}$ & $\begin{array}{r}572,814 \\
192,814\end{array}$ & 237,825 & $\begin{array}{l}137,500 \\
251,500\end{array}$ \\
\hline Antigua & 26,023 & $22,73^{6}$ & 12,174 & 18,00 & 28,000 \\
\hline St Kitts & 33,513 & 34,357 & 31,393 & 35,667 & 37,000 \\
\hline Other British West Indies islands & 5,950 & 6,164 & 12,494 & 11,200 & II, $95^{\circ}$ \\
\hline British Guiana & 172,051 & 165,148 & $172,99 \mathrm{r}$ & 184,690 & 200,877 \\
\hline Total & 638,905 & 596,753 & 595,565 & 779,145 & 823,027 \\
\hline
\end{tabular}


figures for the various colonies for the years $1945-9$ and contains an estimate for 1949-50. The figures show how the industry has expanded during the past 4 years, in fact the maximum increase shown is some 183,000 tons. The retrogradation shown by the total production figures for $1946-8$ can be accounted for by labour troubles and by bad weather conditions that obtained in certain areas. The ultimate increase in production represents a prodigious effort on the part of the estates and farms growing cane and of the factories producing sugar from it. This increase in sugar production, which the estimates for 1949-50 show as still on the upgrade, has been accomplished not only by the planting of fresh tracts of land but also by the use of better methods of cultivation and by the more adequate supply of fertilizers, which were difficult to obtain during the war years. Moreover, sugar factories throughout the British Caribbean have been steadily increasing their efficiency over the past decade, a process which seems to have been accelerated by the formation of the British West Indies Sugar Association in $194 \mathrm{I}$, as a result of which there has been much pooling of knowledge on factory practice.

\section{Future prospects}

Turning to the future, it is important to ascertain to what extent the British Caribbean area could still further increase its sugar production. Competent authorities have declared that an exportable surplus of $1,000,000$ tons/year could be produced within only 2 or 3 years provided that its sale were certain. There is, however, an economic obstacle to such an increase in production. The West Indian sugar producers have always lived in fear of the dumping of cheap foreign sugar in the United Kingdom, which must be their main market. This has, in fact, happened many times in the past and has resulted in the lowering of the price of West Indian sugar and hence of West Indian standards of living as shown by the report of the Lord Soulbury Commission (Commission Appointed to Enquire into the Working of the Sugar Industry in Trinidad, I949).

The sugar producers have been given a guarantee by the Imperial Government for the purchase at a price to be fixed annually of the whole of their exportable surplus until the end of $195^{2}$, and they are now trying to obtain an extension of this until at least 1957. They have not, so far, however, been successful. A guaranteed market and price for 640,000 tons only has been offered, whereas it has been calculated that the West Indies needs to export 800,000 in order to maintain even the present low standard of living of the West Indian workers. However, if these difficulties can be surmounted, the West Indian sugar industry can go forward, and it will be of interest to see how expansion will be possible in practice.

In some islands, St Lucia or Barbados for example, almost the whole of the suitable land is under sugar already, but with others such as Antigua and St Kitts some increase in cane-growing area is possible. Most can be done, however, in Trinidad, Jamaica and British Guiana. According to the findings of the Evans Commission (British Guiana and British Honduras Settlement Commission, 1948) on British Honduras, sugar-cane production could be greatly increased there also. New methods of cultivation, however, appear to offer considerable promise of increasing the production of 
existing sugar plantations. One new system of sugar-cane agriculture, known as the Woodford Lodge System, involves the deeper cultivation of the land ( 18 in. instead of 12 in.) and a much greater mechanization of the operations involved. Table 2 shows the results obtained on an estate using this system, in terms of yield/acre of cane, in relation to neighbouring estates using the old system.

Table 2. Average yield in tons/acre of cane on two estates using the old, and on one estate using the new, system of agriculture

$\begin{array}{cccc}\text { Estate } & \text { System } & 1947 & 1948 \\ X & \text { Old } & 23.46 & 20 \cdot 01 \\ Y & \text { New } & 28.40 & 31 \cdot 20 \\ Z & \text { Old } & 21 \cdot 89 & 23.47\end{array}$

Considerable losses of sugar are incurred by the ravages of insect pests and by plant diseases. Such eminent authorities as Lord Boyd Orr and Viscount Bledisloe have reminded us recently of the serious losses that pests and diseases cause in food crops generally, and in sugar-cane agriculture these agencies do no less damage. The moth borer (Diatraea saccharalis) and the froghopper (Tomaspis saccharina) are the chief insect pests of sugar-cane in the West Indies. The fungus disease, red rot (Colletotrichum falcatum) often attacks the cane at the site of the wounds caused by the insects. Disease problems are being attacked with vigour in the West Indies and means of control are being sought both by biological methods including the importation of suitable parasites, and by the use of modern chemical insecticides. A disease to which sugar-cane is often liable is mosaic-virus disease. This is extremely dangerous and can result in the elimination of whole areas of cane. It was, in fact, responsible for the decline of the Louisiana sugar industry in the middle twenties. Consequently all sugar producers watch carefully for any signs of the onset of this disease. The cane-breeding station for the West Indies, which is situated in Barbados, in carrying out its task of producing higher-yielding varieties of cane tries also to obtain varieties resistant or tolerant to mosaic disease.

Utilization of sugar by-products. Any large increase in the sugar production of the West Indies carries with it the important problem of the efficient disposal of the byproducts of the sugar factory. 'These are filter-press mud, bagasse (the fibre of the cane) and molasses. Hitherto filter-press mud has been returned to the land as fertilizer, but in recent years this procedure has been questioned because this material contains appreciable quantities of wax which is relatively easily extracted. Natural waxes are scarce and are mainly obtainable from hard currency countries and, since sugar-cane wax is similar in properties, it might be of value to extract it from the filter mud before applying this to the fields. Some effort is being made to bring such a scheme, already successful in Louisiana and Australia, into operation in the West Indies.

Bagasse is used throughout the West Indies as factory fuel and as yet no real disposal problem has arisen. As new factories are built and as old factories are modernized, heat efficiency will improve, less bagasse will be needed as fuel and the excess will rapidly become an embarrassment to the factories. Even now the waste burning of hundreds of tons of bagasse is fairly common. Many efforts have been made in the past 
to find uses for bagasse, e.g. as a source of paper and cardboard, of plastics and of structural board, but with the exception of the last none have achieved much success. Nevertheless, considering the greater importance which recent research has put on furfural, its manufacture from bagasse may be a project of some moment in the near future.

An answer to the problem of the utilization of molasses is becoming one of real necessity for the West Indies because, although in the past few years almost all has been used for the manufacture of rum, the market for this commodity is almost saturated and will contract rather than expand. Moreover, it is doubtful whether the shipment of molasses to this country for alcohol manufacture will greatly help the sugar manufacturer. Since molasses contains appreciable quantities of sucrose (about $30 \%$ by weight) and since from 700 to $800 \mathrm{lb}$. are obtained for every ton of sugar made, it could be an important source of sucrose provided recovery were possible. The high concentration of salts in molasses is doubtless partly responsible for preventing the further crystallization of sucrose, and de-ionization with ion-exchange resins has recently been claimed to lead to the production of further amounts of sugar from molasses. It is noteworthy that final molasses has been shown to contain considerable amounts of vitamins of the B group (Rogers \& Mickelson, 1948) in addition to various amino-acids combined with reducing sugars, and if it were possible to render it palatable, molasses might form a useful food product.

Finally, the fact that sugar-cane juice contains appreciable quantities of amino-acids is worthy of mention. An analysis recently carried out by chromatographic methods has shown the presence of alanine, glutamine, asparagine, aspartic acid, glutamic acid, leucine, lysine, valine, serine, glycine and $\gamma$-amino-butyric acid (Pratt \& Wiggins, 1949).

\section{REFERENCES}

British Guiana and British Honduras Settlement Commission (1948). Report [Cmd. 7533]. London: H.M. Stationery Office.

Carr, C. J. (1947). Proc. Soc. exp. Biol., N.Y., 65, 189.

Commission Appointed to Enquire into the Working of the Sugar Industry in Trinidad (r949). Report. Trinidad, B.W.I.: Government Printer.

Floro, M. B., Williams, V., Flook, W. A. \& Collier, J. S. (1948). Int. Sug. J. 50, 234.

Haworth, W. N. \& Wiggins, L. F. (1946). Brit. Pat. no. 583,533.

Haworth, W. N. \& Wiggins, L. F. (1947). Brit. Pat. no. 591,858.

Mack, P. B. (1948). Monographs of the Society for Research in Child Development, 13, no. 1 ; serial no. 46. Washington: National Research Council.

Nichols, P. L. Jr. \& Yanovsky, E. (1947). Sugar, Lond., 42, no. 9, p. 28.

Pratt, O. E. \& Wiggins, L. F. (1949). Proc. Brit. West Indies Sugar Technol. (In the Press.)

Rogers, D. \& Mickelson, M. N. (1948). Industr. Engng Chem. 40, 527.

Sugar Research Foundation (1949). Research and Review, 6th annual report. New York.

Wiggins, L. F. (1949a). Advanc. carbohydr. Chem. 4, 293.

Wiggins, L. F. (1949b). Chem. EF Ind. p. 555. 